\title{
A Case of Familial Isolated Hyperparathyroidism with Ectopic Parathyroid Cancer
}

\author{
Koh YAMASHITA, Satoru SUZUKI, Wataru YUMiTA, Yasuto IKEO, Yumiko UEHARA, \\ KeSAMI MINEMURA, AKIHIRo SAKURAI ANd KIYoshi HASHIZUME
}

Department of Aging Medicine and Geriatrics, Shinshu University School of Medicine, 3-1-1, Asahi, Matsumoto 390-8621, Japan

\begin{abstract}
We report the kindred with familial isolated hyperparathyroidism with parathyroid cancer. The proband was diagnosed as having primary hyperparathyroidism at age 43. The same disorder was also found in his daughter who had low bone mass. His son was found to have primary hyperparathyroidism by family screening. The pathological diagnosis of the resected parathyroid in both father and daughter was parathyroid cancer, and that in son was parathyroid adenoma. The right lower gland of the proband and the left lower gland of the son were present in thymus. No mutations were found in the sequences of MENI gene, hence gene(s) other than MENI gene may have contributed to the malignant potency in our cases.
\end{abstract}

Key words: Familial isolated hyperparathyroidism, Multiple endocrine neoplasia, Hyperparathyroidism, Ectopic parathyroid gland

(Endocrine Journal 48: 453-458, 2001)

PARATHYROID cancer is a rare disorder, whose incidence is approximately less than 1 to $2 \%$ of patients with hyperparathyroidism [1]. Hereditary hyperparathyroidism is also rare, and may manifest as an initial disorder of multiple endocrine neoplasia type 1 (MEN1). On the other hand, benign and malignant forms of familial hyperparathyroidism without associated manifestations of MEN1 have also been described. This familial disorder is denoted as familial isolated hyperparathyroidism (FIHP) $[2,3]$.

We previously reported a case of multiple parathyroid cancer in 1989 [4]. About 10 years later, his daughter and son were found to have primary hyperparathyroidism. The pathological finding of

Received: March 19, 2001

Accepted: May 16, 2001

Correspondence to: Satoru SUZUKI, M.D., Ph.D., Department of Aging Medicine and Geriatrics, Shinshu University School of Medicine, 3-1-1, Asahi, Matsumoto, Nagano 3908621, Japan the resected tumor was parathyroid carcinoma in his daughter. We report this hereditary hyperparathyroidism and discuss about the ectopic glands.

\section{Materials and Methods}

\section{Antibodies}

Rabbit anti-human Ki-67 antibody and horseradish peroxidase-goat anti-rabbit IgG were purchased from Dako Japan (Kyoto).

\section{Immunostaining}

Sections were dewaxed, rehydrated, and endogenous peroxidase was blocked using $0.3 \% \mathrm{H}_{2} \mathrm{O}_{2}$ in methanol for $30 \mathrm{~min}$. Slides were washed in $50 \mathrm{mM}$ Tris-buffered saline (pH 7.6) (TBS). Sections were then reacted with primary antibody diluted at 1:100 for Ki-67 for $30 \mathrm{~min}$ at room temperature. After washing in TBS, sections were incubated with horse- 
radish peroxidase (HRP)-goat anti-rabbit $\mathrm{IgG}$ at a 1:50 dilution for $30 \mathrm{~min}$ at room temperature. After washing in TBS, the sites of HRP were visualized by diaminobenzidine (DAB.) Nuclei were stained with hematoxylin.

\section{Sequencing}

The sequencing was performed as previously described [5].

\section{Case reports}

The kindred is a Japanese family and is currently residing in Nagano Prefecture, Japan. The pedigree of this family is shown in Fig. 1.

Case 1. The patient was admitted to the hospital because of thirst and polyuria in 1988. Levels of serum calcium and C-terminal portion of parathyroid hormone $(\mathrm{PTH})$ were $14.1 \mathrm{mg} / \mathrm{dl}$, and $10.14 \mathrm{ng} / \mathrm{ml}$,

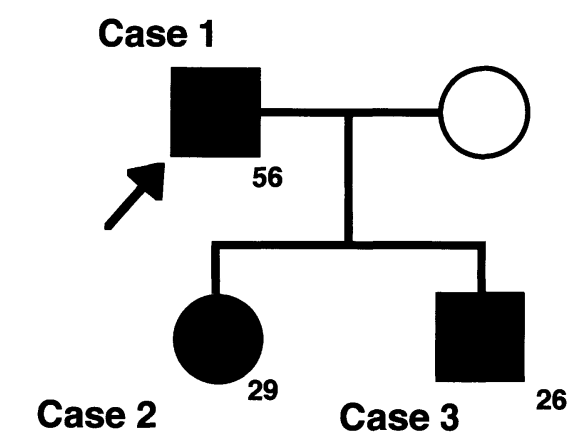

Fig. 1. Pedigree of the family

Patient 1 is proband. The closed and open symbols indicate affected and unaffected family members, respectively. respectively (Table 1). ${ }^{99 m}$ Technesium and ${ }^{201}$ thallium subtraction scintigraphy demonstrated an abnormal accumulation at the right upper and left lower poles of thyroid and right mediastinum (Fig. 2a). The left lower gland and an ectopic parathyroid tumor in thymus were resected under the clinical diagnosis of primary hyperparathyroidism at age 43 . The right upper parathyroid gland could not be found at the operation. As shown in Fig. 3a, there were trabecular growth pattern and capsular invasion in the ectopic parathyroid gland. Numerous mitotic cells and variation in the size and shape of cells were also observed in the resected tumors (data not shown). The pathological diagnosis of both left lower and the ectopic tumor was parathyroid cancer. Levels of serum calcium and PTH decreased after operation. Five years after the initial operation, his serum calcium and PTH increased inappropriately. After an enlarged right upper parathyroid gland was detected and removed, his serum calcium and PTH normalized. The pathological finding of the resected tumor was parathyroid adenoma. Seven years after the second operation, plasma PTH and calcium increased again. ${ }^{99 m}$ Technesium sestamibi scintigraphy and chest CT revealed another ectopic enlarged parathyroid gland in left mediastinum. He has been followed up conservatively because the patient refused surgical resection of the tumor.

Case 2. The daughter of Case 1 was referred to our outpatient clinic because of low bone mass at age 26 . Serum calcium, PTH and index of urinary excretion rate of calcium indicated primary hyperparathyroidism (Table 1). Sestamibi scintigraphy, MRI, CT and US revealed the parathyroid mass in the right upper region of the thyroid gland (Fig. 2b). Because of highly elevated level of plasma PTH $(993 \mathrm{pg} / \mathrm{ml})$

Table 1. Clinical data of the family members on admission.

\begin{tabular}{lcccr}
\hline & Case 1 & Case 2 & Case 3 & \\
\hline Serum Ca $(\mathrm{mg} / \mathrm{dl})$ & 14.1 & 11.5 & 13.5 & $8.6-10.1$ \\
Serum IP $(\mathrm{mg} / \mathrm{dl})$ & 2.3 & 1.5 & 2.3 & $2.2-4.4$ \\
Plasma PTH, C-terminal $(\mathrm{ng} / \mathrm{ml})$ & 10.14 & & & less than 0.6 \\
Plasma Intact PTH $(\mathrm{pg} / \mathrm{ml})$ & & 993 & 930 & $14-66$ \\
$\begin{array}{l}\text { Urinary calcium-to-creatinine } \\
\quad \text { clearance ratio }\end{array}$ & 0.034 & 0.024 & 0.032 & \\
\hline
\end{tabular}

Serum and plasma were obtained after overnight fast and urine was analyzed after 24hour collection. Reference values are shown in the right column. 
a

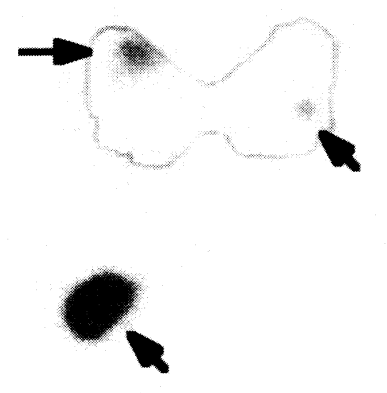

b

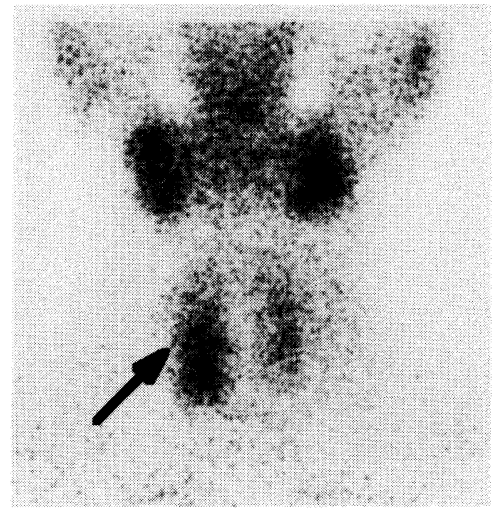



Fig. 2. Scintigraphy of the kindred

(a) Technecium-tallium subtraction scintigraphy in case 1. (b) ${ }^{99 m}$ Technesium Sestamibi scintigraphy in Case 2 . (c) Sestamibi scintigraphy in Case 3. Arrows indicated the abnormal accumulations of the radioisotope suggesting parathyroid tumors.

and a family history, the presence of parathyroid cancer was suspected. Total parathyroidectomy was planned since recurrence of the disease from the residual parathyroid glands was predicted. Enlarged right upper, lower and left upper glands were removed in 1999. Right lobectomy of the thyroid gland was also carried out, since adhesions to the right upper parathyroid gland was observed. Left lower gland was not visible. The resection of contiguous lymph nodes and of left upper region in thymus was performed. Pathologically, strong Ki-67 staining indicated parathyroid cancer in right upper and lower glands [6] although capsular invasion was not detected in the glands (Fig. 3b, c). The pathological diagnosis of the left upper mass was parathyroid hyperplasia. Further, thyroid carcinoma in situ was detected in the resected thyroid gland. There was no parathyroid tissue in the resected upper region of the thymus and the lymph nodes. Levels of plasma intact PTH and serum calcium were diminished after parathyroidectomy. She has been supplemented with calcium and vitamin D.

Case 3. Because two of the kindred had parathyroid cancer, the concentrations of plasma PTH and serum calcium were measured in the proband's wife and son. His wife was normal but his son was also found to have elevated levels of plasma PTH and calcium as shown in Table 1. Sestamibi scintigraphy, MRI, CT and US suggested a parathyroid tumor in left thymus (Fig. 2c). Total parathyroidectomy was considered because of the same reasons of Case 2. Left upper and lower parathyroidectomy, ipsilateral thyroid lobectomy, partial thymomectomy and the resection of contiguous lymph nodes were performed in 1999. The pathological diagnosis of parathyroid adenoma was made in left upper and lower glands because of typical appearance and low frequency of the Ki-67 positive cells as shown in Fig. 3d, e. No abnormality was found in the resected thyroid and lymph nodes. The right parathyroid glands could not be removed because the glands were invisible. His serum calcium decreased after surgical operation and oral administration of supplemental calcium and vitamin D was started.

Radiographical and biochemical screening for MEN1 was performed on all three patients and no evidence of MEN1 was found. Jaw tumors were not found in any of the three patients. Urinary calcium-to-creatinine clearance ratio was not decreased in any of the three cases (Table 1).

To examine the genetic background of this family, blood samples were drawn from family members after written informed consent had been obtained. High-molecular-weight DNA was isolated and the entire coding region of the $M E N 1$ of the Case 2 was sequenced, which revealed no mutations. 


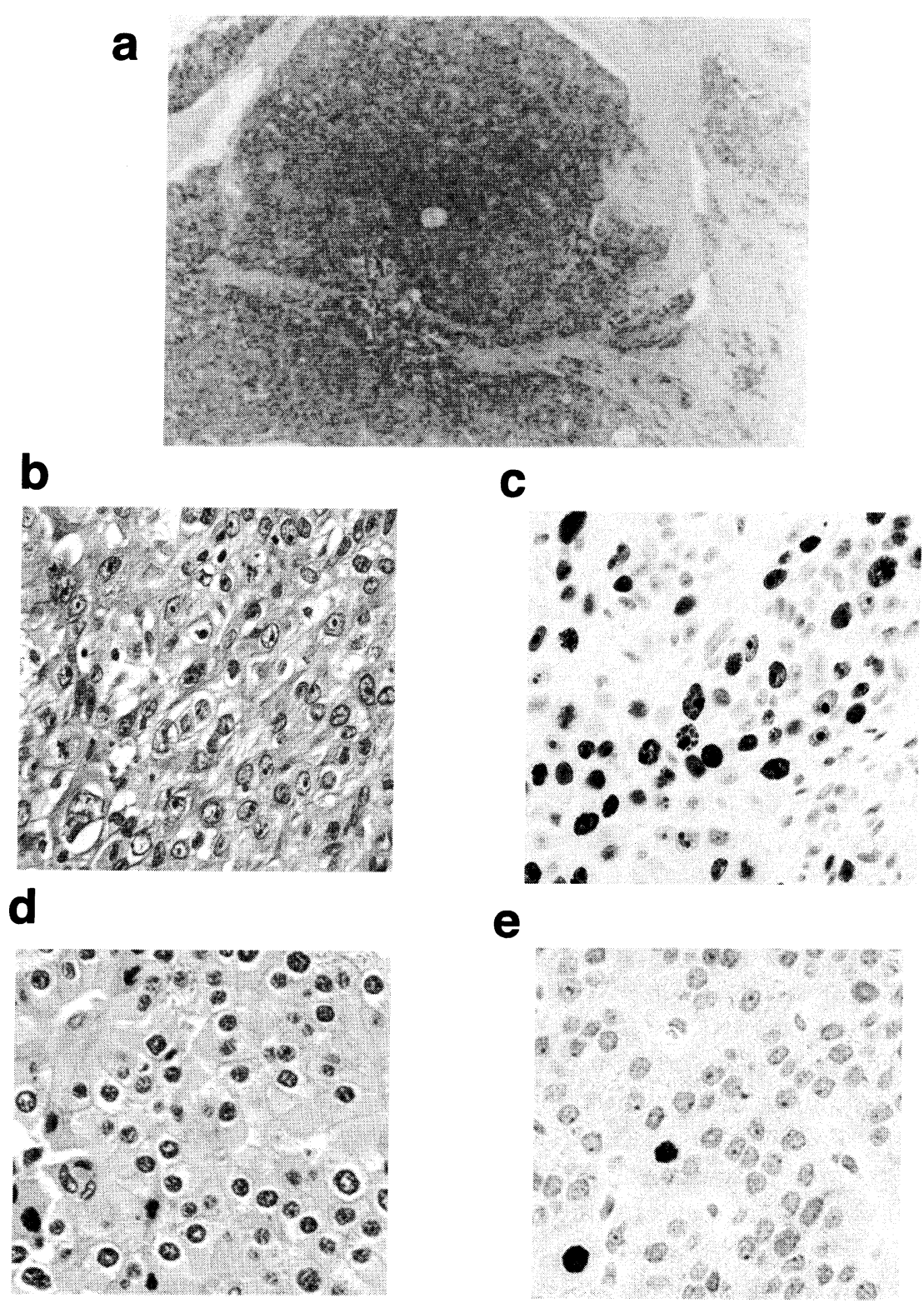

Fig. 3. Hematoxylin-eosin staining (a) showing the ectopic parathyroid gland in Case 1 (4). Hematoxylin-eosin staining (b) showing the right upper parathyroid gland in Case 2. Ki-67 immunostaining (c) showing many proliferating cells with strong staining in the same region. Hematoxylin-eosin staining (d) showing the left lower parathyroid gland in Case 3. Ki-67 immunostaining (e) showing low frequency of the proliferating cells in the same region.

\section{Discussion}

Inherited tumor syndromes constitute a special case in which mutation of one key gene is already present in each somatic cell at birth. Several responsible genes were identified in hereditary endocrine tumors. The germline MENI and RET muta- tions are the predominant causes of MEN1 and MEN2, respectively [7]. Inherited primary hyperparathyroidism without associated manifestation of MEN has been reported, namely, familial isolated hyperparathyroidism (FIHP) [3].

High concentrations of serum PTH and calcium indicated primary hyperparathyroidism as a diagno- 
sis of the affected family members. Another differential diagnosis is familial hypocalciuric hypercalcemia (FHH). FHH is inherited as an autosomal dominant trait with mild to moderate hypercalcemia $[8,9]$. The disorder was reported to be associated with mutations in the human calcium-sensing receptor gene $[10,11]$. Since one of the mutations in calcium-sensing receptor causes the atypical case of familial hypercalcemia with hypercalciuria, which is similar to the primary hyperparathyroidism [12], it may be sometimes difficult to distinguish between FIHP and FHH. The extremely high levels of PTH and calcium, however, suggest primary hyperparathyroidism in these cases. Since urinary calcium-tocreatinine clearance ratio is reported to be low (less than approximately 0.01 ) [8], the ratio in these cases also indicated primary hyperparathyroidism rather than FHH.

There are several subtypes of FIHP based on phenotypical and genotypical assessments. There are families developing primary hyperparathyroidism associated with or without jaw tumors [13]. Genetic analysis demonstrated that there was FIHP in the presence or absence of the mutations of MENI [14]. In our cases, neither jaw tumors nor mutations of the $M E N 1$ gene were found.

Although MENI mutations among some families with isolated hyperparathyroidism have been reported, no mutation was found in the majority of cases, suggesting that genetic defects other than the MENI gene might be involved. $R E T$ is another gene which should be excluded from the pathogenesis of our cases [15]. Dwight et al. demonstrated that sporadic parathyroid tumors were partially linked to not only MEN1 gene but also to two regions of chromosome 1 [16]. One was 1q21-32 for the hyperparathyroidismjaw tumor syndrome, termed the HRPT2 locus; the other one was $1 \mathrm{p}$.
In our three cases, two cases were diagnosed as having carcinoma, another as having adenoma. In Case 1, two of the resected tissues were carcinoma, another one was adenoma. There were carcinoma and hyperplasia in the resected tumors of Case 2. In general, morphological alterations in the development of malignancy may be affected by multistep abnormalities of the oncogenes [17]. Various pathological diagnoses were made in our cases, since different steps in clonal development of parathyroid cancer were observed.

Approximately 5 percent of humans have supernumerary parathyroid glands [18]. The location of the parathyroid glands also varies. The lower glands, which usually lie near the lower pole of the thyroid, may be found in the paratracheal area or close to or within the thymus in the superior mediastinum [18]. Wassif et al. reported that the parathyroid carcinoma in the case of FIHP was located centrally over the isthmus of the thyroid gland [19]. Yoshimoto et al. showed that a normal-sized parathyroid gland was present in the superior mediastinum in a case of familial parathyroid carcinoma [20]. In our cases, two of them had ectopic parathyroid tumors in thymus. Although exact incidence of the ectopic glands is not certain in familial parathyroid carcinoma, it is possible that the abnormal localization of the parathyroid glands is related to the malignant potency of the parathyroid tumor.

In conclusion, we reported three cases of FIHP. Malignant potency may have been affected by gene(s) other than MENI gene in these cases.

\section{Acknowledgement}

We thank Dr. Jun Nakayama for Ki-67 staining of the resected tumors.

\section{Reference}

1. Bringhurst FR, Demay MB, Kronenberg HM (1998) Hormones and disorders of mineral metabolism. In: Wilson JD, Foster DW, Kronenberg HM, Larsen PR (eds) Williams Textbook of Endocrinology. WB Saunders, Philadelphia, 1155-1210.

2. Goldman L, Smyth FS (1936) Hyperparathyroidism in siblings. Ann Surg 104: 971-981.
3. Huang SM, Duh QY, Shaver J, Siperstein AE, Kraimps JL, Clark OH (1997) Familial hyperparathyroidism without multiple endocrine neoplasia. World J Surg 21: 22-28.

4. Suzuki S, Hashizume K, Ichikawa K, Nagasawa Y, Yamada T (1990) A case of Multiple Primary Parathyroid Carcinoma. Naika 66: 376-378 (in Japanese). 
5. Chandrasekharappa SC, Guru SC, Manickam P, Olufemi SE, Collins FS, Emmert-Buck MR, Debelenko LV, Zhuang Z, Lubensky IA, Liotta LA, Crabtree JS, Wang Y, Roe BA, Weisemann J, Boguski MS, Agarwal SK, Kester MB, Kim YS, Heppner C, Dong Q, Spiegel AM, Burns AL, Marx SJ (1997) Positional cloning of the gene for multiple endocrine neoplasia-type 1. Science: 404-407.

6. Farnebo F, Auer G, Farnebo LO, The BT, Twigg S, Aspenblad U, Thompson NW, Grimelius L, Larsson C, Sandelin K (1999) Evaluation of retinoblastoma and $\mathrm{Ki}-67$ immunostaining as diagnostic markers of benign and malignant parathyroid disease. World $J$ Surg 23: 68-74.

7. Marx SJ, Agarwal SK, Kester MB, Heppner C, Kim YS, Skarulis MC, James PK, Goldsmith PK, Saggar SK, Park SY, Spiegel AM, Burns AL, Debelenko LV, Zhuang Z, Lubensky IA, Liotta LA, Emmert-Buck MR, Guru SC, Manickam P, Crabtree J, Erdos MR, Collins FS, Chandrasekharappa SC (1999) Multiple endocrine neoplasia type 1: clinical and genetic features of the hereditary endocrine neoplasias. Recent Prog Horm Res 54: 397-438.

8. Marx SJ, Attie MF, Levine MA, Spiegel AM, Downs RW, Lasker RD (1981) The hypocalciuric or benign variant of familial hypercalcemia: clinical and biochemical features in fifteen kindreds. Medicine 60: 397-412.

9. Kanazawa H, Tanaka H, Kodama S, Moriwake T, Kobayashi M, Seino Y (2000) The effect of calciumsensing receptor gene polymorphisms on serum calcium levels: A familial hypo-calciuric hypercalcemia family without mutation in the calcium-sensing receptor gene. Endocr J 47: 29-35.

10. Brown EB, Gamba G, Riccardi D, Lombardi M, Butters R, Kifor O, Sun A, Hediger MA, Lytton J, Hebert SC (1993) Cloning and characterization of an extracellular $\mathrm{Ca} 2+$-sensing receptor from bovine parathyroid. Nature 366: 575-580.

11. Pollak MR, Brown EM, Chou YH, Hebert SC, Marx SJ, Steinmann B, Levi T, Seidman CE, Seidman JG (1993) Mutations in the human $\mathrm{Ca}(2+)$-sensing receptor gene cause familial hypocalciuric hypercalcemia and neonatal severe hyperparathyroidism. Cell 75: 1297-1303.

12. Carling T, Szabo E, Bai M, Ridefelt P, Westin G, Gustavsson P, Trivedi S, Hellman P, Brown EM, Dahl N, Rastad J (2000) Familial hypercalcemia and hypercalciuria caused by a novel mutation in the cytoplasmic tail of the calcium receptor. J Clin Endocrinol Metab 85: 2042-2047.

13. Teh BT, Farnebo F, Twigg S, Hoog A, Kytola S, Korpi-Hyovalti F, Wong FK, Nordenstrom J, Grimelius L, Sandelin K, Robinson B, Farnebo L-O, Larsson C (1998) Familial isolated hyperparathyroidism maps to the hyperparathyroidism-jaw tumor locus in 1q21-q32 in a subset of families. $J$ Clin Endocrinol Metab 83: 2114-2120.

14. Teh BT, Esapa CT, Houlston R, Grandell U, Farnebo F, Nordenskjold M, Pearce CJ, Carmichael D, Larsson C, Harris PE (1998) A family with isolated hyperparathyroidism segregating a missense MEN1 mutation and showing loss of the wild-type alleles in the parathyroid tumors. Am J Hurn Genet 63: 15441549.

15. Schuffenecker I, Virally-Monod $M$, Brohet $R$, Goldgar D, Conte-Devolx B, Leclerc L, Chabre O, Boneu A, Caron J, Houdent C, Modigliani E, Rohmer V, Schlumberger M, Eng C, Guillausseau PJ, Lenoir GM (1998) Risk and penetrance of primary hyperparathyroidism in multiple endocrine neoplasia type 2A families with mutations at codon 634 of the RET proto-oncogene. Groupe D'etude des Tumeurs a Calcitonine. J Clin Endocrinol Metab: 487-491.

16. Dwight T, Twigg S, Delbridge L, Wong F-K, Farnebo F, Richardson AL, Nelson A, Zedenius J, Philips J, Larsson C, Teh BT, Robinson B (2000) Loss of heterozygosity in sporadic parathyroid tumors: involvement of chromosome 1 and the MEN1 gene locus in 11q13. Clin Endocrinol 53: 85-92.

17. Nowell PC (1976) The clonal evolution of tumor cell populations. Science 194: 23-28.

18. Le HN, Norton JA (2001) Surgical management of hyperparathyroidism. In: DeGroot LJ, Jameson JL (eds) Endocrinology. WB Saunders, Philadelphia, 1111-1120.

19. Wassif WS, Moniz CF, Friedman E, Wong S, Weber G, Nordenskjold M, Peters TJ, Larsson C (1993) Familial isolated hyperparathyroidism: A distinct genetic entity with an increased risk of parathyroid cancer. J Clin Endocrinol Metab 77: 1485-1489.

20. Yoshimoto K, Endo H, Tsuyuguchi M, Tanaka C, Kimura T, Iwahana H, Kato G, Sano T, Itakura M (1998) Familial isolated primary hyperparathyroidism with parathyroid carcinomas: clinical and molecular features. Clin Endocrinol (Oxf) 48: 67-72. 